\title{
Review of health and non-health sector indicators for monitoring service provision along the continuum of care for maternal health
}

\author{
Mamothena Carol Mothupi* ${ }^{*}$, Lucia Knight@ and Hanani Tabana
}

\begin{abstract}
Objective: This study uses health and non-health sector data sources to select and assess available indicators for service provision along the continuum of care for maternal health at subnational levels in South Africa. It applies the adequacy approach established in another study to assess the multi-dimensionality of available indicators. Using adequacy and the process of assessment in the study, the comprehensiveness of the continuum of care for improving maternal health outcomes can be assessed.

Results: We found 27 indicators of care utilization and access, linkages of care, and quality of care from the routine district health information system. The General Household Survey contained 11 indicators for the social determinants of health on the continuum of care framework. Indicator gaps include health promotion during and after pregnancy, maternal nutrition, empowerment and quality of care. At present, the available indicators measure about $74 \%$ of the interventions on the continuum of care framework. We make recommendations regarding improvements needed to better measure and monitor the continuum of care for maternal health. These involve actions within the health system and include integration of non-health system indicators.
\end{abstract}

Keywords: Continuum of care for maternal health, Health service indicators, Social determinants of health indicators, Adequacy construct for the continuum of care for maternal health

\section{Introduction}

The continuum of care is a strategy for improving the efficiency and effectiveness of service delivery for maternal health $[1,2]$. It is the delivery of services from preconception to the postnatal period, including those related to social determinants of health. The continuum of care $(\mathrm{CoC})$ framework, developed by national stakeholders in South Africa, is presented in Fig. 1. It outlines linked intervention packages from the family/community to the district level of care. South Africa (SA) has a strategic goal to deliver and monitor services along the $\mathrm{CoC}$ in maternal and related health areas $[3,4]$. However, there is

*Correspondence: mamothena@gmail.com

University of the Western Cape School of Public Health, Robert Sobukwe Rd, Bellville, Cape Town 7535, South Africa a gap in defining the indicator set for monitoring service delivery (mainly inputs, outputs and processes) along the $\mathrm{CoC}$ to support these goals.

In a previous study, we described the construct of adequacy, which emerged from a systematic review and critical interpretive synthesis of gaps in measurement of the $\mathrm{CoC}$ [5]. The adequacy approach states that the $\mathrm{CoC}$ should be measured and monitored in a comprehensive and multidimensional manner. This means all aspects of timely access to care, quality of care, linkages between levels of care, and social determinants of health should be measured. The framework in Fig. 1 guides the essential interventions and highlights their linkages, while the adequacy approach integrates multidimensional quality of care measurement.. In this study we used the framework in Fig. 1 and the adequacy construct to (i) propose 


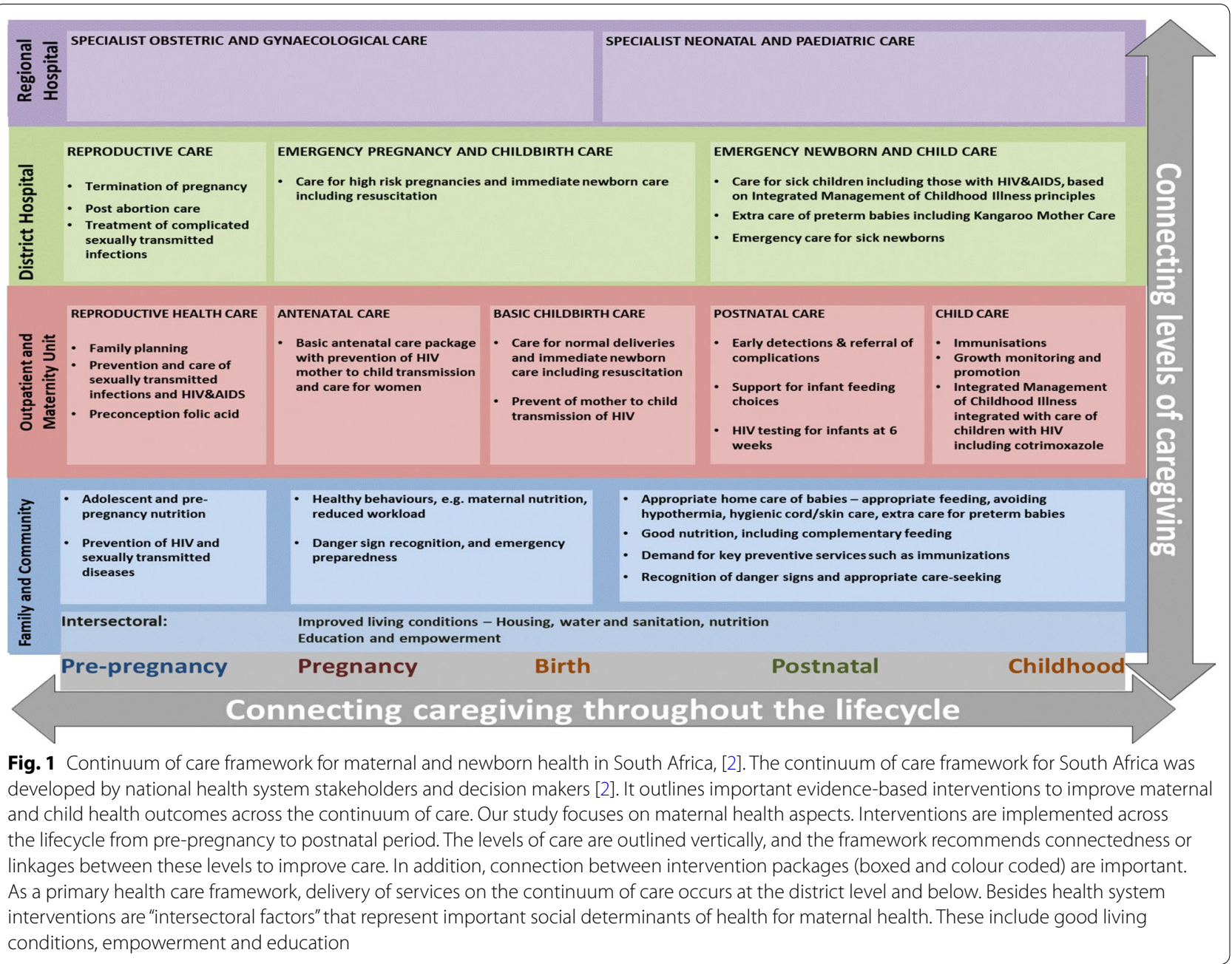

an indicator tool for the $\mathrm{CoC}$ for maternal health in SA, and (ii) describe current gaps to be addressed in improving monitoring and provision of services.

\section{Main text \\ Methods}

In this study we assess available indicators currently used for health and non-health sector policy and planning in government programs. They thus have a defined monitoring purpose which is re-assessed for suitability to the CoC framework.

\section{Indicator extraction}

We used the routine district health information system (DHIS) to extract relevant health system indicators. The DHIS monitors health programmes, track patients and map service availability in the health system in SA [6]. The National Indicator Data Set (NIDS) within the DHIS contains indicators of service inputs, processes, outputs and outcomes (where relevant) extracted for this study, for the reference period April 2017-March 2019 [7]. For social determinants of health/intersectoral factors as outlined in Fig. 1, we assessed datasets on the Statistics SA Nesstar portal and selected the General Household Survey (GHS) (reference year 2017) as the most suitable source. The GHS is annually collected and contains data on all intersectoral factors, which are used in policy and planning in SA $[8,9]$. All GHS data can be obtained from the DataFirst Portal of the University of Cape Town in SA [10].

\section{Indicator evaluation}

The health service indicators from the DHIS were evaluated for suitability to the framework based on their current monitoring purposes and recommendations from existing guidelines. These guidelines included:

- Annual performance plans of the Department of Health in SA.

- Guidelines for maternity care in South Africa. 
- The strategic objectives of the global network to improve Quality, Equity and Dignity in maternal, newborn and child health [11].

- Resources exploring the WHO Quality of Care Framework for maternal and new-born health [12, 13].

- Global Review of Key Interventions related to reproductive, maternal, newborn and child health [14].

- Guidelines for positive birth experience with a focus on monitoring Intrapartum care [15].

- Quality of care at primary (Ideal Clinic Realization and Maintenance Program) and hospital (National Core Standards) level in SA [16, 17].

For social determinants of health, we relied on literature focusing on the relationship between interventions and maternal health outcomes. We also relied on recommendations by the WHO and Commission on Social Determinants of Health [18], conceptual framework of the social determinants of health [19], and frameworks for practice at country level [20]. The evaluation of indicators also revealed outstanding gaps in measuring interventions on the framework, which we describe in this study.

\section{Results}

\section{Indicator set}

In Fig. 2 we present a set of 38 indicators that were extracted and evaluated from the DHIS and GHS (27 indicators from the health system and 11 for the intersectoral factors). The figure also describes measurement gaps per intervention package of the $\mathrm{CoC}$. As Fig. 2 shows, indicators are available for most of the intervention packages on the $\mathrm{CoC}$ framework. The exceptions were danger sign recognition and emergency preparedness, healthy behaviour promotion and indicators for emergency pregnancy care. The lack of indicators demonstrates unavailable services and/or poor monitoring by the health system. Sometimes indicators are available that do not directly measure maternal health outcomes. Figure 2 shows proxies such as food fortification compliance rates (Indicator 3 ) used by the health system at community level. Other proxies include Ideal Clinic status (Indicator 20) and national core standards (Indicator 21), which are summary measures of quality of care at facility level. Where only proxies are available, we recommend health information system improvements to measure and integrate measures that are more directly related to maternal health outcomes.

Even where indicators are available, measurement improvements can be made in order to monitor each intervention package comprehensively. Each intervention package consists of more than one intervention, as shown in Fig. 1. For example, while Reproductive Care at district hospital may include timely termination of pregnancy indicators, there is a gap in monitoring postabortion care and treatment of complicated STIs as part of the package. Thus, more research is needed to assess the extent to which the health system provides services within each intervention package of the CoC. New health system interventions, such as Human Papillomavirus (HPV) vaccinations for school going girls and health promotion through mobile phones (MomConnect program), should be monitored through the DHIS. This will improve the comprehensiveness of the data set and ease of monitoring the $\mathrm{CoC}$ in the health system.

Quality of care was an under-measured aspect of interventions such as antenatal care visits, normal and Caesarean deliveries, and postnatal visits. There is a need for intervention specific qualities of care indicators, as exemplified by retest rates for HIV positive clients during antenatal care (Indicator 11, Fig. 2). The health system runs parallel quality of care systems for maternal health, particularly the confidential maternal mortality audits [21]. We recommend the establishment of routine measures from these sources for integration into the DHIS. Routine quality of care monitoring should also include reporting of safety incidents and experience of care surveys disaggregated by population groups.

While indicators are available for the intersectoral factors in the framework, we observed gaps in monitoring indoor air pollution, maternal nutrition counselling, and women's empowerment for decision making and demand for healthcare. Like health system interventions, each intersectoral factor could be measured by more than one indicator. For instance, in the water and sanitation intervention package, the GHS had variables that could assess safety of water, infrastructure and basic sanitation (Indicators 28-30). While educational achievement indicators may be straightforward, factors such as empowerment and nutrition are more multifaceted. Thus, a variety of indicators can be isolated for their measurement, depending on data availability.

In summary, Fig. 2 is the indicator tool which provides a description of available indicators and gaps that need to be addressed to monitor the $\mathrm{CoC}$ for maternal health. The gaps identified should not preclude use of the tool to assess the nature and extent of provision of services along the $\mathrm{CoC}$ for maternal health in future studies. The improvement and validation of indicators in maternal health should be a continuous process, tied to evolving policies and information system improvements [22].

\section{Adequacy assessment}

In Fig. 3 indicators are grouped according to adequacy dimensions, and the information in Fig. 2 used to 


\begin{tabular}{|c|c|c|c|c|c|c|}
\hline & Level of care & $\begin{array}{l}\text { Intervention } \\
\text { package }\end{array}$ & Indicator(s) & $\begin{array}{l}\text { Data } \\
\text { Source }\end{array}$ & Description & Gaps \\
\hline $1-2$ & \multirow[t]{2}{*}{$\begin{array}{l}\text { Pre-pregnancy/ } \\
\text { Community }\end{array}$} & Reproductive Health & $\begin{array}{l}\text { Female and male } \\
\text { condom } \\
\text { distribution } \\
\text { coverage }\end{array}$ & DHIS & $\begin{array}{l}\text { Condoms distributed from a primary } \\
\text { distribution site to health facilities or points in } \\
\text { the community (e.g. campaigns, non- } \\
\text { traditional outlets, etc.) }\end{array}$ & $\begin{array}{l}\text { There is need to monitor screening and } \\
\text { vaccination for Human Papilloma Virus } \\
\text { (HPV) as per new policy of vaccinations to } \\
\text { school going girls. }\end{array}$ \\
\hline 3 & & $\begin{array}{l}\text { Adolescent/ } \\
\text { Preconception } \\
\text { nutrition }\end{array}$ & $\begin{array}{l}\text { Mills fortification } \\
\text { compliance rate }\end{array}$ & DHIS & $\begin{array}{l}\text { Operational flour and maize milling } \\
\text { establishments that were compliant with } \\
\text { fortification Regulation under the FCD Act as } \\
\text { a proportion of milling establishments that } \\
\text { were inspected. }\end{array}$ & $\begin{array}{l}\text { This indicator reflects community level } \\
\text { exposure. More indicators can be explored } \\
\text { that are directly related to adolescent and } \\
\text { preconception nutrition, such as provision of } \\
\text { micronutrient supplementation. }\end{array}$ \\
\hline 4 & $\begin{array}{l}\text { Pre-pregnancy } \\
\text { /Primary health } \\
\text { facility }\end{array}$ & Reproductive Health & $\begin{array}{l}\text { Couple year } \\
\text { protection rate }\end{array}$ & DHIS & $\begin{array}{l}\text { Women protected against pregnancy by using } \\
\text { modern contraceptive methods, including } \\
\text { sterilisations, as proportion of female } \\
\text { population } 15-49 \text { years. }\end{array}$ & Need to monitor post-partum family planning \\
\hline 5-7 & $\begin{array}{l}\text { Pre-pregnancy/ } \\
\text { District hospital }\end{array}$ & Reproductive Care & $\begin{array}{l}\text { Termination of } \\
\text { pregnancy }-0-12 \\
\text { weeks rate, } 13-20 \\
\text { weeks rate and } \\
\text { under } 20 \text { years rate }\end{array}$ & DHIS & $\begin{array}{l}\text { Pregnancies terminated in health facilities in } \\
\text { at specified gestation period time, or age of } \\
\text { woman, as a proportion of total termination of } \\
\text { pregnancies }\end{array}$ & $\begin{array}{l}\text { Need to monitor post abortion care and } \\
\text { treatment of complicated STIs. }\end{array}$ \\
\hline \multirow[t]{2}{*}{8} & \multirow[t]{2}{*}{$\begin{array}{l}\text { Pregnancy/ } \\
\text { Community }\end{array}$} & Healthy behaviours & & & & $\begin{array}{l}\text { Outreach to households through ward based } \\
\text { outreach teams could potentially include } \\
\text { health promotion to encourage health } \\
\text { behaviours. In addition, the MomConnect } \\
\text { platform which distributes cellphone } \\
\text { messages for pregnant women can promote } \\
\text { healthy behaviours. It is important to monitor } \\
\text { the promotion of healthy behaviours through } \\
\text { these interventions and antenatal care } \\
\text { services. }\end{array}$ \\
\hline & & $\begin{array}{l}\text { Danger sign } \\
\text { recognition and } \\
\text { emergency } \\
\text { preparedness }\end{array}$ & & & & $\begin{array}{l}\text { Indicators that monitor interventions such as } \\
\text { MomConnect which uses cellphone messages } \\
\text { to promote healthy pregnancies need to be } \\
\text { integrated into the DHIS as scale up in public } \\
\text { health facilities in the country increase. }\end{array}$ \\
\hline 9 & Pregnancy/Primary & Antenatal Care & Antenatal 1st visit & DHIS & Women who have a booking visit (first visit) & Monitoring of content of care during \\
\hline \multirow[b]{2}{*}{10} & \multirow[t]{5}{*}{ health facility } & \multirow[t]{5}{*}{ (with PMTCT) } & $\begin{array}{l}\text { before } 20 \text { weeks } \\
\text { rate }\end{array}$ & & $\begin{array}{l}\text { before they are } 20 \text { weeks into their pregnancy } \\
\text { as proportion of all antenatal } 1 \text { st visits }\end{array}$ & $\begin{array}{l}\text { antenatal care as included in clinical } \\
\text { management modules of the Ideal Clinic } \\
\text { quality improvement assessment tools. }\end{array}$ \\
\hline & & & $\begin{array}{l}\text { Antenatal 1st visit } \\
\text { coverage }\end{array}$ & DHIS & $\begin{array}{l}\text { The proportion of potential antenatal clients } \\
\text { coming for at least one (booking) antenatal } \\
\text { visit. The census number of children under } \\
\text { one year factorised by } 1.15 \text { is used as a proxy } \\
\text { denominator - the extra } 0.15 \text { ( } 15 \% \text { ) is a rough } \\
\text { estimate to cater for late miscarriages ( } ~ 10 \text { to } \\
26 \mathrm{w}) \text {, stillbirths (after } 26 \text { weeks gestation) } \\
\text { and infant mortality. Pregnant women are } \\
\text { regarded as potential antenatal clients from } \\
\text { around } 10 \text { weeks' gestation, i.e. spontaneous } \\
\text { abortions before that as well as ToP cases are } \\
\text { excluded }\end{array}$ & \\
\hline 11 & & & $\begin{array}{l}\text { Antenatal client } \\
\text { HIV re-test rate: } \\
\text { retesting among } \\
\text { positive HIV clients }\end{array}$ & DHIS & $\begin{array}{l}\text { Antenatal clients re-tested for HIV as } \\
\text { proportion of antenatal clients tested negative } \\
\text { for } 1 \text { st HIV tests done during current } \\
\text { pregnancy }\end{array}$ & $\begin{array}{l}\text { Besides HIV, there is need to integrate } \\
\text { monitoring indicators for TB diagnosis and } \\
\text { treatment. }\end{array}$ \\
\hline 12 & & & $\begin{array}{l}\text { Antenatal client } \\
\text { start on ART rate }\end{array}$ & DHIS & $\begin{array}{l}\text { Antenatal clients who started on ART as a } \\
\text { proportion of the total number of antenatal } \\
\text { clients who are HIV positive and not } \\
\text { previously on ART }\end{array}$ & \\
\hline $\begin{array}{l}13- \\
15\end{array}$ & & & $\begin{array}{l}\text { Syphilis positive } \\
\text { pregnant female } \\
\text { receive Benz- } \\
\text { penicillin } 1^{\text {st }}, 2^{\text {nd }} \\
\text { and } 3^{R D} \text { dose rate }\end{array}$ & DHIS & $\begin{array}{l}\text { Syphilis positive pregnant females who } \\
\text { received Benz-penicillin } 1^{\text {st }}, 2^{\text {nd }} \text { or } 3^{\text {rd }} \text { dose as } \\
\text { a proportion of pregnant females who tested } \\
\text { positive for syphilis }\end{array}$ & \\
\hline & $\begin{array}{l}\text { Pregnancy/ District } \\
\text { hospital }\end{array}$ & Reproductive Care & $\begin{array}{l}\text { Emergency } \\
\text { pregnancy care }\end{array}$ & DHIS & & $\begin{array}{l}\text { Need for indicators of high risk pregnancy } \\
\text { care to be integrated into the DHIS }\end{array}$ \\
\hline 16 & $\begin{array}{l}\text { Birth/Primary } \\
\text { health facility }\end{array}$ & $\begin{array}{l}\text { Care for normal } \\
\text { delivery and } \\
\text { PMTCT }\end{array}$ & $\begin{array}{l}\text { Delivery in facility } \\
\text { rate }\end{array}$ & DHIS & $\begin{array}{l}\text { Deliveries in health facilities as proportion of } \\
\text { expected deliveries in the population. } \\
\text { Expected deliveries are estimated as } \\
\text { population under } 1 \text { year multiplied by } 1.025 \\
\text { to compensate for still births and infant } \\
\text { mortality }\end{array}$ & $\begin{array}{l}\text { Indicators for management of post-partum } \\
\text { haemorrhage and other quality of care signal } \\
\text { functions during childbirth needed. }\end{array}$ \\
\hline 17 & $\begin{array}{l}\text { Birth/ District } \\
\text { hospital }\end{array}$ & $\begin{array}{l}\text { Emergency } \\
\text { childbirth care }\end{array}$ & $\begin{array}{l}\text { Delivery by } \\
\text { caesarean section }\end{array}$ & DHIS & $\begin{array}{l}\text { Delivery by Caesarean section as proportion } \\
\text { of total deliveries in health facilities }\end{array}$ & $\begin{array}{l}\text { Need to monitor quality of care during } \\
\text { Caesarean deliveries }\end{array}$ \\
\hline
\end{tabular}

Fig. 2 Description of indicators and gaps in monitoring interventions along the continuum of care for maternal health in South Africa. The indicator tool was developed to summarize available indicators, their source, and the data gaps that were observed in the study of the continuum of care for maternal health in South Africa. The levels of care and intervention package columns are based on the continuum of care framework developed by health system actors, and presented in Fig. 1 of this study, and indicators are grouped together to make the figure more concise (e.g. indicators 5-7 represents three indicators within the reproductive care package). The detailed definition and numerator and denominators of each indicator can be found in the metadata of the relevant data sources as specified in the Figure. The description of indicators gives a general guidance of the measures involved. Data gaps are also summaries from literature, global and national guidelines as specified in the manuscript 


\begin{tabular}{|c|c|c|c|c|c|c|}
\hline & Level of care & $\begin{array}{l}\text { Intervention } \\
\text { package }\end{array}$ & Indicator(s) & $\begin{array}{l}\text { Data } \\
\text { Source }\end{array}$ & Description & Gaps \\
\hline & & & rate & & & \\
\hline 18 & $\begin{array}{l}\text { Post-natal care/ } \\
\text { Community }\end{array}$ & $\begin{array}{l}\text { Recognition of } \\
\text { danger signs and } \\
\text { care-seeking }\end{array}$ & & & & $\begin{array}{l}\text { Outreach to households }(\mathrm{OHH}) \text { with postnatal } \\
\text { care indicators may include recognition of } \\
\text { danger signs and care seeking. However, } \\
\text { current indicators only monitor visits and not } \\
\text { the content of care. This intervention is also } \\
\text { not provided to all women who deliver in } \\
\text { public facilities. }\end{array}$ \\
\hline 19 & $\begin{array}{l}\text { Post-natal care/ } \\
\text { Primary health } \\
\text { facility }\end{array}$ & $\begin{array}{l}\text { Early detection and } \\
\text { referral of } \\
\text { complications }\end{array}$ & $\begin{array}{l}\text { Mother postnatal } \\
\text { visit within } 6 \text { days } \\
\text { rate }\end{array}$ & DHIS & $\begin{array}{l}\text { Mothers who received postnatal care within } 6 \\
\text { days after delivery as proportion of deliveries } \\
\text { in health facilities }\end{array}$ & $\begin{array}{l}\text { Need to monitor the content of care in } \\
\text { postnatal visits or obstetric referrals }\end{array}$ \\
\hline 20 & $\begin{array}{l}\text { Quality of care/ } \\
\text { Primary health } \\
\text { facility }\end{array}$ & Cross-cutting & $\begin{array}{l}\text { Ideal Clinic Status } \\
\text { rate }\end{array}$ & DHIS & $\begin{array}{l}\text { Score out of } 100 \text { based on multidimensional } \\
\text { measure of quality environment with some } \\
\text { signal functions for maternal health; reflects } \\
\text { national priorities at primary care level. The } \\
\text { main dimensions include } 1 \text {. Administration } 2 \text {. } \\
\text { Integrated Clinical Services Management } 3 \text {. } \\
\text { Medicines, Supplies and Laboratory Services } \\
\text { 4. Human Resources for Health 5. Support } \\
\text { Services } 6 \text {. Infrastructure } 7 \text {. Health } \\
\text { Information Management } 8 \text {. Communication } \\
\text { 9. District Health System Support } 10 \text {. } \\
\text { Implementing Partners and Stakeholders. All } \\
\text { main dimensions have sub-components and } \\
\text { specific elements to be measured. }\end{array}$ & $\begin{array}{l}\text { May be supplemented with more detailed } \\
\text { signal function data e.g. from the } \\
\text { department's maternal death audits and } \\
\text { observational data. Reporting specific } \\
\text { maternal health safety incidents using newly } \\
\text { developed tool for Patient Safety Incident } \\
\text { Reporting and Learning to be reported with } \\
\text { future Ideal Clinic related data. }\end{array}$ \\
\hline 21 & $\begin{array}{l}\text { Quality of care/ } \\
\text { District Hospital }\end{array}$ & Cross-cutting & $\begin{array}{l}\text { Hospital achieved } \\
75 \% \text { and more on } \\
\text { National Core } \\
\text { Standards (NCS) } \\
\text { self-assessment rate }\end{array}$ & DHIS & $\begin{array}{l}\text { Score out of } 100 \text { on a multidimensional } \\
\text { measure of quality environment, without } \\
\text { signal functions for maternal health. } \\
\text { Availability of guidelines for clinical } \\
\text { management of gynaecological/obstetric } \\
\text { conditions assessed via the NCS. 1: Patient } \\
\text { Rights 2: Patient Safety, Clinical Governance } \\
\text { and Clinical Care 3: Clinical Support Services } \\
\text { 4: Public Health 5: Leadership and } \\
\text { Governance 6: Operational Management 7: } \\
\text { Facilities and Infrastructure. }\end{array}$ & $\begin{array}{l}\text { May be supplemented with more detailed } \\
\text { signal function data e.g. from the } \\
\text { department's maternal death audits and } \\
\text { observational data. }\end{array}$ \\
\hline \multirow[t]{2}{*}{$22-$} & $\begin{array}{l}\text { Linkages of care/ } \\
\text { Crosscutting }\end{array}$ & Cross-cutting & $\begin{array}{l}\text { Obstetric } \\
\text { emergency inter- }\end{array}$ & DHIS & $\begin{array}{l}\text { Emergency obstetric inter-facility transfers } \\
\text { response times under } 60 \text { minutes as a }\end{array}$ & $\begin{array}{l}\text { Linkages across packages of care can be } \\
\text { explored through research and formulation of }\end{array}$ \\
\hline & & & $\begin{array}{l}\text { facility transfer } \\
\text { rates }\end{array}$ & & $\begin{array}{l}\text { proportion of EMS obstetric rural inter- } \\
\text { facility transfers; Emergency obstetric inter- } \\
\text { facility transfers response times under } 30 \\
\text { minutes as a proportion of EMS obstetric } \\
\text { urban inter-facility transfers }\end{array}$ & new indicators \\
\hline $\begin{array}{l}24- \\
26\end{array}$ & & & $\begin{array}{l}\text { Obstetric response } \\
\text { times and client } \\
\text { transport rates }\end{array}$ & DHIS & $\begin{array}{l}\text { Obstetric clients as a proportion of total EMS } \\
\text { clients transported }\end{array}$ & \\
\hline 27 & $\begin{array}{l}\text { Cross- } \\
\text { cutting/Community } \\
\text { (Intersectoral } \\
\text { Factors) }\end{array}$ & Water and sanitation & $\begin{array}{l}\text { Environmental } \\
\text { Health: Domestic } \\
\text { water compliance } \\
\text { rate }\end{array}$ & DHIS & $\begin{array}{l}\text { Domestic bacteriological and chemical water } \\
\text { samples taken from Water Services } \\
\text { Authorities and water service intermediaries } \\
\text { at a point of use that conform to the standards } \\
\text { set out in SANS } 241 \text { for drinking water } \\
\text { quality and safety as a proportion of water } \\
\text { samples collected }\end{array}$ & $\begin{array}{l}\text { Similar sanitation indicators may be collected } \\
\text { by the health system as part of their } \\
\text { Environmental Health assessment. }\end{array}$ \\
\hline 28 & & Water and sanitation & $\begin{array}{l}\% \text { women } 15-49 \\
\text { drinking safe water }\end{array}$ & GHS & $\begin{array}{l}\text { Proportion of women } 15-49 \text { in households } \\
\text { that perceive their water to be safe }\end{array}$ & \\
\hline 29 & & & $\begin{array}{l}\% \text { women } 15-49 \text { in } \\
\text { households with } \\
\text { adequate water } \\
\text { infrastructure }\end{array}$ & GHS & $\begin{array}{l}\text { Proportion of women } 15-49 \text { in households } \\
\text { with adequate water supply infrastructure }\end{array}$ & \\
\hline 30 & & & $\begin{array}{l}\% \text { women } 15-49 \\
\text { with basic } \\
\text { sanitation facility }\end{array}$ & GHS & $\begin{array}{l}\text { Proportion of women } 15-49 \text { in households } \\
\text { with basic sanitation facilities. }\end{array}$ & \\
\hline 31 & & Housing & $\begin{array}{l}\% \text { women } 15-49 \\
\text { with access to } \\
\text { electricity }\end{array}$ & GHS & $\begin{array}{l}\text { Proportion of women } 15-49 \text { in households } \\
\text { with access to electricity }\end{array}$ & $\begin{array}{l}\text { Exploration of more reliable measures of } \\
\text { indoor air pollution; current variables } \\
\text { integrate both outdoor and air pollution from } \\
\text { the perspective of households. }\end{array}$ \\
\hline 32 & & & $\begin{array}{l}\% \text { women } 15-49 \\
\text { living in adequate } \\
\text { housing }\end{array}$ & GHS & $\begin{array}{l}\text { Proportion of women } 15-49 \text { living in } \\
\text { households with "good" or "very good" wall, } \\
\text { roof, and floor condition of the dwelling. }\end{array}$ & \\
\hline 33 & & & $\begin{array}{l}\% \text { women } 15-49 \\
\text { living in formal } \\
\text { housing }\end{array}$ & GHS & $\begin{array}{l}\text { Proportion of women } 15-49 \text { in housing } \\
\text { classified as formal housing (by Regional } \\
\text { Development Plan (RDP) plan of the country) }\end{array}$ & \\
\hline 34 & & Nutrition & $\begin{array}{l}\% \text { women } 15-49 \\
\text { who have adequate } \\
\text { food access }\end{array}$ & GHS & $\begin{array}{l}\text { The mean proportion of women } 15-49 \text { in } \\
\text { households that "never" had insufficient food, } \\
\text { run out of money for food, cut the size of } \\
\text { meals, skip a meal, or small variety of meals. }\end{array}$ & $\begin{array}{l}\text { May be supplemented with other sources of } \\
\text { data on macro and micronutrient variety. } \\
\text { Intervention/nutrition counselling (health } \\
\text { promotion) on lifestyle factors that impact }\end{array}$ \\
\hline
\end{tabular}

Fig. 2 continued 


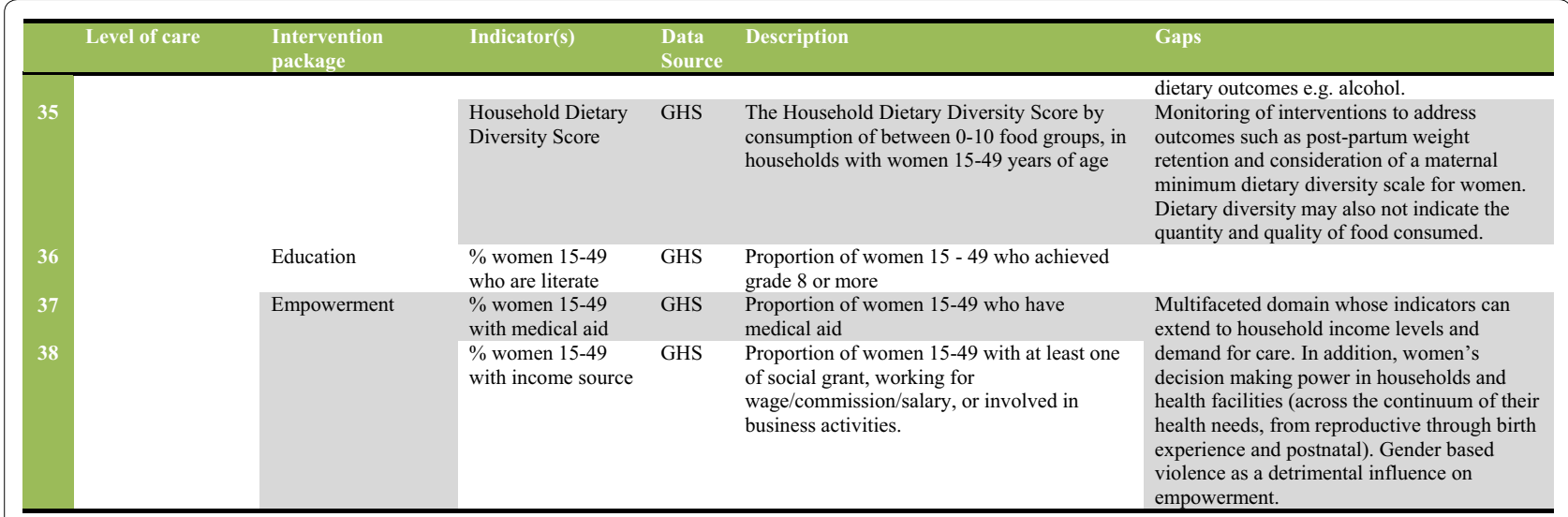

Fig. 2 continued

subjectively assess the level to which intervention packages can be measured by available indicators. We assign "partial" (orange) measurement if indicators are available but there are measurement gaps identified. When assigned "no" (red) if no indicators or proxies were identified from the data sources. And we assigned "yes" (green) if, according to literature and existing guidelines, there are indicators available to measure the intervention package. Availability of indicators for an intervention package does not preclude future rigorous validation processes and iterations; this is a normal process within the health information system that is encouraged.

All dimensions of the $\mathrm{CoC}$ can be measured by current indicators, although gaps remain within specific intervention packages. Data gaps were most prevalent in the care access and utilization dimension, where $40 \%(6 / 15)$ of intervention packages had no indicators available. Dimensions of quality and linkages of care can only be partially measured; while only $40 \%(2 / 5)$ of social determinants of health domains have available indicators. In general, the GHS and the DHIS provide indicator data for measurement and monitoring of the majority (74\%) of $\mathrm{CoC}$ intervention packages $(17 / 23)$ as defined by the framework in Fig. 1.

\section{Discussion}

This study developed and assessed the indicator tool for the continuum of care framework for maternal health in South Africa. This process can be applied to newborn and child health indicators within the framework, using relevant data sources. These processes contribute to the operationalization of the framework, in order to fulfil health system goals in comprehensive monitoring and evaluation of maternal health [23]. Our study also advances the application of the adequacy approach to assess the multi-dimensionality of the available indicators. The adequacy approach complements the framework developed by health system actors by integrating quality of care measures. The $\mathrm{CoC}$ has been criticized for under-emphasizing quality of care [24]. For instance, there is still a gap in monitoring quality of care signal functions for maternal health through the DHIS. Data from many programs in the health system are collected separately and only later incorporated into the DHIS [25]. We recommend future research for assessing feasibility of integration of quality of care and service programs data into the routine monitoring and evaluation systems.

Interventions that signify "linkages of care" were also not well defined prior to our study. For that purpose, we proposed the use of indicators for patient transport from community to facility and in-between facilities. Transport facilitates referrals between different levels of care, and an important determinant of maternal mortality in SA [21]. Referrals encompass not only transport but also matching skills to patient needs and managing congestion in facilities [21]. Thus, more research is needed to identify indicators for monitoring human resources and patient management factors in facilities that can contribute to the framework. Our study identified a gap in linkages between one intervention package and another, which is also an important determinant of maternal health outcomes [26, 27]. The $\mathrm{CoC}$ framework improves on the country's strategic plan because it includes more social determinants than water and sanitation [23]. Other frameworks propose even more social determinants, such as occupation, social class, race and ethnicity, social environment and psychosocial circumstances, and behavioural factors [19]. In this study we focused on the domains specified by the framework and recommend future research to explore feasibility of additional indicators. 


\begin{tabular}{|c|c|c|c|}
\hline Dimension & Level of care & Intervention package & $\begin{array}{l}\text { Indicators/proxies } \\
\text { available }\end{array}$ \\
\hline \multirow[t]{15}{*}{$\begin{array}{l}\text { Timely access and } \\
\text { utilization of care }\end{array}$} & \multirow[t]{2}{*}{$\begin{array}{l}\text { Family and community/Pre- } \\
\text { pregnancy }\end{array}$} & $\begin{array}{l}\text { Adolescence and pre- } \\
\text { pregnancy nutrition }\end{array}$ & Yes \\
\hline & & Prevention of HIV/STIs & Yes \\
\hline & \multirow[t]{2}{*}{ Family and community/Pregnancy } & Healthy Behaviour & No \\
\hline & & $\begin{array}{l}\text { Danger Sign Recognition and } \\
\text { Emergency Preparedness }\end{array}$ & No \\
\hline & Family and Community/Postnatal & $\begin{array}{l}\text { Danger sign recognition and } \\
\text { appropriate care seeking, } \\
\text { nutrition }\end{array}$ & No \\
\hline & \multirow{3}{*}{$\begin{array}{l}\text { Primary health facility/ Pre- } \\
\text { pregnancy }\end{array}$} & Family planning & Yes \\
\hline & & Prevention of HIV/STIS & Yes \\
\hline & & Preconception folic acid & No \\
\hline & Primary health facility/Pregnancy & $\begin{array}{l}\text { Basic Antenatal Care with } \\
\text { PMTCT }\end{array}$ & Yes \\
\hline & Primary health facility/Childbirth & Care for normal deliveries & Yes \\
\hline & $\begin{array}{l}\text { Primary health facility/ Postnatal } \\
\text { care }\end{array}$ & $\begin{array}{l}\text { Early detection and referral of } \\
\text { complications }\end{array}$ & Partial \\
\hline & \multirow[t]{3}{*}{ District Hospital / Pre-pregnancy } & Termination of pregnancy & Yes \\
\hline & & Post-abortion care & No \\
\hline & & Treatment of complicated STIs & No \\
\hline & $\begin{array}{l}\text { District Hospital /Emergency } \\
\text { Pregnancy and Childbirth Care }\end{array}$ & Care for high risk pregnancies & Partial \\
\hline \multirow[t]{2}{*}{ Quality of Care } & District Hospital/Crosscutting & $\begin{array}{l}\text { Quality of care at secondary } \\
\text { level }\end{array}$ & Partial \\
\hline & $\begin{array}{l}\text { Primary health facility/cross- } \\
\text { cutting }\end{array}$ & Quality of care at primary level & Partial \\
\hline Linkages of care & All levels/cross-cutting & $\begin{array}{l}\text { Linkages of care levels } \\
\text { (referrals) }\end{array}$ & Partial \\
\hline \multirow{5}{*}{$\begin{array}{l}\text { Intersectoral } \\
\text { factors/social } \\
\text { determinants of health }\end{array}$} & \multirow{5}{*}{$\begin{array}{l}\text { Family and community/cross- } \\
\text { cutting }\end{array}$} & Housing & Partial \\
\hline & & Water and Sanitation & Yes \\
\hline & & Nutrition & Partial \\
\hline & & Empowerment & Partial \\
\hline & & Education & Yes \\
\hline
\end{tabular}

Fig. 3 Assessment of availability of indicators over dimensions and domains of the continuum of care for maternal health in South Africa. The dimensions of the continuum of care are defined according to the adequacy construct developed in a previous study [5]. The level of care and intervention packages contain indicators found in Fig. 2 and are based on the continuum of care framework in Fig. 1. We assign "partial" (orange) measurement if indicators are available but there are measurement gaps identified. When assigned "no" (red) when no indicators or proxies were identified from the data sources. And we assigned "yes" (green) if, according to literature and existing guidelines, the indicators available to measure the intervention package are considered adequate

In conclusion, this study proposed a multidimensional, comprehensive indicator set that can be used to assess the continuum of maternal health care in public health research and practice. The indicator set integrates the under-specified aspects of the framework, such as quality of care and broader social determinants of health, thus improving its potential use from a multisectoral perspective.

\section{Limitations}

The indicators used are only applicable to the South African context, but the adequacy model can be used by researchers from other LMICs to guide a multidimensional analysis of information in their context. We identified and assessed indicators only for the intervention packages outlined in the $\mathrm{CoC}$ framework and the dimensions proposed through the adequacy model. We 
recommend on-going research to refine the framework and indicators suitable for maternal health $\mathrm{CoC}$.

\section{Abbreviations}

CoC: Continuum of Care; DHIS: District Health Information Systems; GHS: General Household Survey; HPV: Human Papillomavirus; LMIC: Low- and Middle-Income Countries; NIDS: National Indicator Data Set; SA: South Africa; STIs: Sexually Transmitted IIInesses; WHO: World Health Organization.

\section{Acknowledgements}

Not applicable

\section{Authors' contributions}

MM and LM conceptualized the study. MM conducted data collection and analysis. LM and HM guided additional analysis of data. MM, LM, HT were involved in writing and revision of manuscript. All authors read and approved the final manuscript.

\section{Funding}

This work is based on the research supported by the South African Research Chairs Initiative of the Department of Science and Technology and National Research Foundation of South Africa (Grant No. 82769). The authors would also like to acknowledge funding from the South African Medical Research Council and the Belgian Development Cooperation, through the Institute of Tropical Medicine Antwerp. Any opinion, finding and conclusion or recommendation expressed in this material is that of the authors and not the funders. The funders did not have a role in the design of the study and collection, analysis, and interpretation of data and in writing the manuscript.

\section{Availability of data and materials}

The datasets generated and/or analysed for the General Household Survey during the current study are available in the DataFirst repository, [https:// www.datafirst.uct.ac.za/dataportal/index.php/catalog/central] [10]. The datasets generated and/or analysed for the District Health Information System during the current study are available in the National Department of Health Data Dictionary repository, [https://dd.dhmis.org/] [7].

\section{Ethics approval and consent to participate}

Not applicable.

\section{Consent for publication}

Not applicable.

\section{Competing interests}

The authors declare that they have no competing interests.

Received: 24 January 2020 Accepted: 26 February 2020

Published online: 13 March 2020

\section{References}

1. Kerber KJ, de Graft-Johnson JE, Bhutta ZA, Okong P, Starrs A, Lawn JE. Continuum of care for maternal, newborn, and child health: from slogan to service delivery. Lancet. 2007;370(9595):1358-69.

2. Bradshaw D, et al. Every death counts: saving the lives of mothers, babies and children in South Africa. Cape Town: Department of Health; 2008.

3. Department of Health. Strategic plan for maternal, newborn, child and women's health (MNCWH) and nutrition in South Africa: 2012-2016, Pretoria, South Africa; 2012.

4. Department of Health. Integrated Clinical Services Management, Pretoria; 2015.

5. Mothupi M, Knight L, Tabana H. Measurement approaches in continuum of care for maternal health: a critical interpretive synthesis of evidence from LMICs and its implications for the South African context. BMC Health Serv Res. 2018;18(539):1-9.

6. Department of Health. District health management information system (DHMIS) policy, Pretoria; 2011

7. Department of Health. Data File: NIDS Integrated. The NDOH Data Diction ary, 2019. https://dd.dhmis.org/orgunits.html?file=NIDSIntegrated\&sourc $\mathrm{e}=$ nids\&ver=22b8. Accessed 09 Sept 2020.

8. Department of Planning Monitoring and Evaluation. Development indicators 2011, Pretoria; 2011.

9. Statistics South Africa. General household survey: selected development indicators 2016, Pretoria; 2017.

10. Statistics South Africa. Open Data Portal, DataFirst, 2019. https://www datafirst.uct.ac.za/dataportal/index.php/catalog/central. Accessed 09 Jan 2020

11. WHO. Quality, equity, dignity: the network to improve quality of care for maternal, newborn and child health. Geneva: World Health Organization; 2018

12. Brizuela V, Leslie HH, Sharma J, Langer A, Tunçalp Ö. "Measuring quality of care for all women and newborns: how do we know if we are doing it right? A review of facility assessment tools. Lancet Global Health. 2019;7(5):e624-32.

13. Tunçalp Ö, et al. Quality of care for pregnant women and newborns-the WHO vision. BJOG An Int J Obstet Gynaecol. 2015;122(8):1045-9.

14. The Partnership For Maternal Newborn \& Child Health. A global review of key interventions related to reproductive, maternal, newborn and child health. Geneva: World Health Organisation; 2011.

15. WHO. Intrapartum care for a positive childbirth experience. Geneva: World Health Organization; 2018.

16. Department of Health. Ideal Clinic Definitions, Components and Checklists, Pretoria, 2018.

17. Department of Health. Towards Quality Care for Patients. National Core Standards for Health Establishments in South Africa, Pretoria, 2011.

18. Commission on Social Determinants of Health. Closing the gap in a generation: health equity through action on the social determinants of health. Geneva: World Health Organization; 2008.

19. Solar O, Irwin A. A conceptual framework for action on the social determinants of health: social determinants of health discussion paper 2 (Policy and Practice). Geneva: World Health Organization; 2010.

20. WHO. Closing the gap: policy into practice for social determinants of health. Geneva: World Health Organization; 2011.

21. Department of Health. Saving mothers 2014-2016: seventh triennial report on confidential enquiries into maternal deaths in South Africa: executive summary, Pretoria; 2016.

22. Benova L, Moller A, Moran AC. 'What gets measured better gets done better': the landscape of validation of global maternal and newborn health indicators through key informant interviews. PLoS ONE. 2019;14(11):1-16.

23. Department of Health, Strategic plan for maternal, newborn, child and women's health (MNCWH) and nutrition in South Africa: 2012-2016, Pretoria; 2012.

24. Graham WJ, Varghese B. Quality, quality, quality: gaps in the continuum of care. Lancet. 2012;379(9811):e5-6.

25. Wright G, O'Mahony D, Cilliers L. Electronic health information systems for public health care in South Africa: a review of current operational systems. J Health Inform Africa. 2017;4(1):51-7.

26. Pattinson RC. Report to UNICEF on the scaling-up of the BANC quality improvement programme in two sub-districts per province in South Africa. Pretoria: MRC Maternal and Infant Health Care Strategies Research Unit and the University of Pretoria; 2007.

27. Kikuchi K, et al. Effective linkages of continuum of care for improving neonatal, perinatal, and maternal mortality: a systematic review and meta-analysis. PLoS ONE. 2015;10(9):e0139288.

\section{Publisher's Note}

Springer Nature remains neutral with regard to jurisdictional claims in published maps and institutional affiliations. 